Jurnal Dinamika Manajemen, 5 (1) 2014, 103-120

\title{
PENINGKATAN EFEKTIVITAS PROGRAM STUDI DI PERGURUAN TINGGI SWASTA MELALUI KEPEMIMPINAN ADAPTIF INTEGRATIF
}

\author{
S. Martono ${ }^{\varpi}$, Andhi Wijayanto \\ Fakultas Ekonomi, Universitas Negeri Semarang, Semarang, Indonesia
}

\section{Info Artikel}

Sejarah Artikel:

Diterima November 2013

Disetujui September 2013

Dipublikasikan Maret 2014

Keywords:

Effectiveness;

Adaptive Leadership;

Job Satisfaction;

Commitmen.

\begin{abstract}
Abstrak
Penelitian ini bertujuan untuk mengembangkan dasar teori model konseptual resolusi kepemimpinan dan konflik, mengamati pengaruhnya untuk kepuasan kerja, komitmen dan efektivitas organisasi. Penelitian ini melakukan tes empiris mengenai hubungan antara variabel-variabel, yaitu gaya kepemimpinan adaptif, resolusi konflik, kepuasan kerja, komitmen afektif dan efektivitas organisasi. Penelitian ini mengembangkan model teoritis empiris sebagai dasar untuk menguji dan menganalisis konflik substantif dan gaya kepemimpinan adaptif integratif dan juga implikasinya terhadap otonomi tugas, kerja sama tim, kepuasan kerja, komitmen organisasi dan efektivitas program studi di universitas. Sampel dari penelitian ini adalah program studi utama dan atau departemen dari PTS di Kota Semarang. Path Analysis dengan Structural Equation Model digunakan untuk menganalisa dan menguji hipotesis. Penelitian ini telah mengungkapkan temuan baru, yaitu kemampuan gaya kepemimpinan adaptif integratif menjadi mediasi antara hubungan kepuasan kerja dan efektifitas organisasi.
\end{abstract}

\section{IMPROVING THE EFFECTIVENESS OF STUDY PROGRAMS AT PRIVATE UNIVERSITIES THROUGH INTEGRATIVE ADAPTIVE LEADERSHIP}

\begin{abstract}
The objective of the research is to develop a conceptual model of the basic theory of resolution leadership and conflict, to observe the influence of job satisfaction, commitment and organizational effectiveness. It is an empirical study to test the relationship of the variables such as adaptive leadership style, conflict resolution, job satisfaction, affective commitment and organizational effectiveness. The study develops an empirical theoretical model as a basis to test and analyze the substantive conflict and integrative adaptive leadership style and also the implications for task autonomy, teamwork, job satisfaction, organizational commitment and study programs effectiveness at the university. The samples of the study are the main study programs or departments at private universities in Semarang. The data were analyzed by Path Analysis with Structural Equation Model to analyze and test the hypothesis. The result of the study shows the new finding; it is the ability of integrative adaptive leadership style becomes the mediation between job satisfaction and organizational effectiveness.
\end{abstract}

JEL Classification: M0, M5, M54

Alamat korespondensi : 


\section{PENDAHULUAN}

Dalam lingkungan organisasi pendidikan, khususnya perguruan tinggi, salah satu ukuran efektivitas organisasi ditunjukkan adanya tingkat ketercapaian akreditasi. Suatu unit dan program studi yang telah terakreditasi dapat diartikan mampu mencapai tujuannya karena untuk mendapatkan nilai "baik" harus mencapai nilai/ skor tertentu. Skor tersebut diperoleh berdasarkan tingkat ketercapaian berbagai komponen akreditasi yang telah ditentukan seperti aspek pengembangan akademik, kemahasiswaan, sumber daya manusia, serta kualitas dan pengembangan profesional (Zakuan et al., 2012).

Pengukuran efektivitas organisasi Perguruan Tinggi berbasis komponen akreditasi menggambarkan kemampuan lembaga mencapai kualitas sistem pendidikan, khususnya yang berkaitan dengan Tri Dharma Perguruan Tinggi. Pencapaian skor/nilai akreditasi "A" menuntut kekuatan dan komitmen semua unsur yang ada di dalam unit satuan program studi. Untuk mencapai nilai tinggi, suatu unit program studi harus didukung sumber daya yang memadai. Namun, kenyataannya justru sumber daya pendukung relatif sangat terbatas. Hal ini memunculkan berbagai permasalahan, diantaranya konflik dalam organisasi, komitmen dan kepuasan kerja mengingat tidak semua sumber daya termasuk sumber daya manusia yang dibutuhkan dalam suatu program studi tersedia sehingga untuk memenuhinya harus bekerjasama dengan program studi lain. Selain itu, gaya kepemimpinan yang ada juga dapat mempengaruhi konflik yang terjadi serta komitmen dan kepuasan kerja pegawai yang bersangkutan.

Penelitian House (1971) mengidentifikasi berbagai pendekatan kepemimpinan yang paling sering diteliti, yaitu pendekatan trait (sifat), behavior (perilaku) dan situational (situasional). Pendekatan dalam memahami hubungan antara pimpinan dan bawahan memunculkan model kepemimpinan transaksional, transformasional dan karismatik. Pemimpin transaksional membantu anggota organisasi untuk mengidentifikasi perilaku agar mencapai hasil yang lebih berkua- litas. Kepemimpinan transformasional berusaha memotivasi karyawan untuk bekerja mencapai tujuan bukan hanya untuk kepentingan pribadi jangka pendek, tetapi untuk mencapai prestasi dan aktualisasi diri (McLaurin \& Al Amri, 2008). Tipe kepemimpinan karismatik berusaha mewujudkan atmosfer motivasi atas dasar komitmen dan identitas emosional pada visi, filosofi, dan gaya pimpinan dalam diri bawahannya (McLaurin \& $\mathrm{Al} \mathrm{Amri,} \mathrm{2008).} \mathrm{Hubungan} \mathrm{antara} \mathrm{ke-}$ pemimpinan transaksional dan transformasional memunculkan gaya kepemimpinan adaptif (Yulk \& Mashud, 2011).

Pemimpin yang adaptif selalu berusaha mengenali peluang dan tantangan yang dipadukan dengan kekuatan internal. Kepemimpinan adaptif didefinisikan sebagai pola interaktif di mana pengetahuan, tindakan preferensi, dan perubahan perilaku mampu merangsang sebuah organisasi untuk menjadi lebih adaptif (Lichtenstein, 2006 \& Burke, 2007). Kepemimpinan adaptif tidak akan mengharapkan pengikutnya untuk mengikuti keinginan pemimpin, sebaliknya kepemimpinan terjadi ketika pola interaksi mewujudkan hasil adaptif. Pemimpin memberi tanggung jawab kepada karyawan untuk menyelesaikan masalahnya, dan membiarkan karyawan merasakan adanya tekanan eksternal, dan ketidaksepahaman di antara karyawan. Tugas pemimpin melindungi dan memberikan arahan dalam mengelola konflik dan membentuk norma.

Secara spesifik Kilmann dan Thomas (1977), mengembangkan gaya resolusi konflik berdasarkan dua dimensi, yaitu kerjasama sebagai upaya untuk memuaskan orang lain jika menghadapi konflik dan keasertifan sebagai upaya untuk memuaskan diri sendiri jika menghadapi konflik. Dua sudut pandang ini memunculkan lima pendekatan yang berbeda dalam upaya menyelesaikan konflik (Kilmann \& Thomas, 1977) seperti yang ditunjukkan dalam Gambar 1, yaitu pendekatan dominasi, akomodasi, kolaborasi, menghindar dan kompromi.

Penelitian ini menggunakan pendekatan kolaboratif dalam menyelesaikan konflik 
atau masalah dengan pertimbangan hasil penelitian Euwema et al. (2003) yang menegaskan, bahwa resolusi kolaboratif berhubungan positif dengan konflik tugas atau kognitif. Pencapaian kinerja diperoleh dari karyawan yang memiliki komitmen, saling ketergantungan tugas untuk mencapai tujuan organisasi melalui hubungan yang saling percaya dan saling menghormati (Griffin, 2012).

Komitmen organisasi merupakan merupakan sikap yang merefleksikan loyalitas karyawan pada organisasi (Fitriastuti, 2013). Komitmen organisasi memiliki pengaruh terhadap besar kecilnya kinerja. Komitmen organisasi sendiri salah satunya dipengaruhi oleh kepuasan kerja. Kepuasan kerja adalah sebagai pertanda awal komitmen organisasional (Ranihusna, 2010). Penelitian ini berfokus pada komitmen afektif, yaitu kekuatan relatif identifikasi individu dan keterlibatannya dengan organisasi tertentu.

Diharapkan, bahwa karyawan dengan komitmen afektif yang kuat dalam organisasi karena mereka menginginkannya, terutama didasarkan pada ikatan emosional pada organisasi (Meyer et al., 2008). Dengan demikian, komitmen afektif untuk meningkatkan keinginan karyawan akan tetap berada dalam organisasi. Komitmen afektif telah menjadi dimensi yang paling banyak dipelajari dan divalidasi (Caykoylu et al., 2007) dan yang paling kuat terkait dengan sejumlah variabel, termasuk pergantian tenaga kerja, prestasi kerja, kepuasan kerja dan komunikasi.
Karyawan dengan komitmen afektif tinggi mungkin akan setia dan sangat melekat pada organisasi, sehingga mengurangi kemungkinan pergantian tenaga kerja tinggi (Meyer et al., 2008). Hal ini juga diharapkan bahwa karyawan yang menunjukkan komitmen afektif yang lebih besar kemungkinan untuk bekerja keras. Karakteristik pekerjaan dan lingkungan kerja cenderung mempengaruhi perkembangan komitmen afektif. Komitmen tinggi akan menentukan tingkat kepuasan seseorang dalam bekerja (Lambert et al., 2006 \& Markovits, 2007).

Kepuasan kerja adalah sikap umum karyawan terhadap pekerjaannya dan secara langsung mengikat pada kebutuhan individu termasuk pekerjaan yang menantang, penghargaan yang adil, lingkungan kerja dan teman sejawat yang mendukung (Moynihan \& Pandey 2007). Dalam kehidupan organisasi modern, kepuasan kerja dijadikan ukuran tingkat kematangan organisasi, merupakan tanda bahwa organisasi dikelola dengan baik yang pada dasarnya adalah hasil manajemen efektif (Leung et al., 2008). Kepuasan kerja menurut Griffin (2012) dapat diterangkan berdasarkan tiga macam teori, yaitu expectancy theory (teori pengharapan), equity theory (teori keadilan), dan two factor theory (teori dua faktor). Salah satu hal yang mampu menciptakan kepuasan adalah adanya otonomi tugas yang dirasakan oleh karyawan.

Penelitian Patillo (2009) menjelaskan, bahwa otonomi tugas merupakan kebebasan mengembangkan pola dan strategi dalam me-

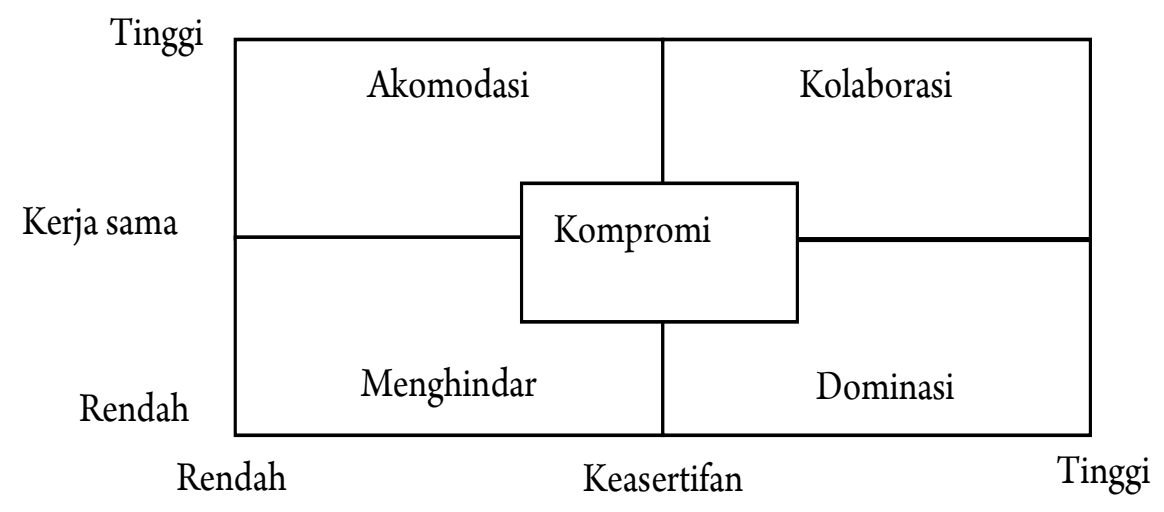

Gambar 1. Model Penyelesaian Konflik 
nyelesaikan tugas atau pekerjaan. Kebebasan dalam menyelesaikan tugas berarti seorang karyawan diberikan keluasan sesuai daya kreativitas dan inovasinya. Otonomi tugas yang tinggi bagi seorang karyawan dapat menimbulkan dan meningkatkan kemauan keras untuk melaksanakan suatu kegiatan yang menjadi tanggung jawabnya dan bahkan tidak segan-segan karyawan tersebut melaksanakan tugas di luar peran formalnya. Dari hasil penelitian terdahulu terdapat beberapa research gap terkait dengan variabel konflik substantif, kerjasama tim dan otonomi tugas disajikan pada Tabel 1.

Efektivitas organisasi diukur dari tingkat ketercapaian tujuan. Efektivitas organisasi terdiri dari individu dan kelompok, karena itu efektivitas organisasi terdiri dari efektivitas individu dan kelompok (Kok-Yee Ng, 2008). Namun demikian, efektivitas organisasi adalah lebih banyak dari jumlah efektivitas individu dan kelompok, sehingga organisasi dapat efektif jika mampu mendapatkan hasil karya yang lebih tinggi tingkatannya dari pada jumlah hasil karya setiap bagiannya.

Menurut data di Kopertis 6 terdapat 310 program studi $S 1$ di perguruan tinggi swasta di
Kota Semarang yang termasuk dalam kelompok universitas dan Institut yang berada di bawah Kopertis 6 Jawa Tengah. Dari jumlah tersebut yang terakreditasi "A" dan "B" mencapai 155 program studi. Jumlah program studi yang telah terakreditasi tersebut menunjukkan, bahwa kualitas program studi di PTS termasuk dalam kategori tinggi.

Tingginya program studi yang telah terakreditasi tersebut ternyata belum menjamin homogenitas persepsi antara ketua program studi atau jurusan dan dosen. Unsur pimpinan program studi atau jurusan berusaha untuk meningkatkan ketersediaan kelengkapan administratif sebagai pendukung akreditasi, sementara tidak semua dosen menyusun dokumen pendukung kegiatan akademik.

Kesenjangan kualitas dapat terjadi sebagai akibat variasi program studi. Artinya, tiap perguruan tinggi memiliki karakteristik dalam mengembangkan program studinya yang pada akhirnya berdampak pada nilai akreditasi, sementara nilai akreditasi dipergunakan oleh stakeholder sebagai salah satu syarat untuk menilai kualitas lulusan. Banyak lembaga yang mensyaratkan lulusan agar dapat melamar dan diterima menjadi pegawai harus memiliki nilai akreditasi

Tabel 1. Research Gap Isu Konflik substantif, Kerjasama tim, Otonomi tugas, dan Kepuasan Kerja

\begin{tabular}{|c|c|c|}
\hline No & Peneliti & Temuan \\
\hline 1. & Jehn (1995) & $\begin{array}{l}\text { Konflik substantif berpengaruh negatif terhadap kepuasan } \\
\text { kerja. Dengan kata lain, konflik substantif akan menurunkan } \\
\text { kepuasan kerja. } \\
\text { Konflik substantif berpengaruh positif terhadap kepuasan } \\
\text { kerja, atau konflik substantif akan meningkatkan kepuasan } \\
\text { kerja }\end{array}$ \\
\hline 2. & $\begin{array}{l}\text { Tjosvold et al. (2006); } \\
\text { Aritzeta et al. (2005) }\end{array}$ & $\begin{array}{l}\text { Konflik substantif atau konflik tugas tidak berpengaruh } \\
\text { terhadap kerjasama tim. }\end{array}$ \\
\hline 3. & Furumo (2009) & $\begin{array}{l}\text { Konflik substantif berpengaruh positif terhadap kerjasama } \\
\text { tim, atau konflik substantif akan meningkatkan kerjasama tim. }\end{array}$ \\
\hline 4. & $\begin{array}{l}\text { Chan et al. (2004) Ali } \\
\text { dan Baloch (2010) }\end{array}$ & $\begin{array}{l}\text { Otonomi tugas berpengaruh positif terhadap kepuasan kerja, } \\
\text { atau otonomi tugas akan meningkatkan kepuasan kerja }\end{array}$ \\
\hline & $\begin{array}{l}\text { Morris dan Venkatesh } \\
(2010) \text {; Galup et al. } \\
(2008)\end{array}$ & Otonomi tugas tidak berpengaruh terhadap kepuasan kerja \\
\hline
\end{tabular}


program studi sekurang-kurangnya B. Sehubungan dengan itu, setiap program studi harus berusaha untuk meningkatkan nilai akreditasinya. Namun, faktanya tidaklah mudah menggerakkan sumber daya organisasi dalam upaya meningkatkan kualitas program studi, terutama sumber daya manusia.

Berdasarkan research gap dan fenomena manajemen, maka permasalahan penelitian yang diajukan dalam penelitian ini adalah: "Bagaimana peran pemimpin dalam proses resolusi konflik substantif serta implikasinya terhadap kerjasama tim, komitmen afektif, kepuasan kerja dan efektivitas organisasi?" Berdasarkan masalah penelitian yang diajukan di atas, dilakukan elaborasi menjadi beberapa pertanyaan penelitian yang diajukan dalam penelitian empirik sebagai berikut: (1) Apakah gaya kepemimpinan adaptif dapat meningkatkan kerjasama tim, kepuasan kerja dan efektivitas organisasi?; (2) Apakah resolusi konflik substantif dapat meningkatkan kerjasama tim, komitmen, kepuasan kerja, dan efektivitas organisasi?

Manfaat dari penelitian ini dapat mencakup manfaat teoritis dan praktis. Penelitian ini memiliki kegunaan praktis sebagai berikut: (1) Pengujian secara empiris dengan mengintegrasikan berbagai faktor personal dan organisasional diharapkan memberikan wacana bagi praktik-praktik organisasi pendidikan di tingkat perguruan tinggi swasta, khususnya di Kota Semarang dan (2) Memberikan kontribusi pemikiran bagi para pimpinan, khususnya di pendidikan tinggi, yang menekankan bahwa gaya kepemimpinan adaptif integratif dalam membangun konflik substantif dan fungsional merupakan pilihan sebagai pertimbangan untuk meningkatkan kepuasan kerja, komitmen dan efektivitas organisasi.

\section{Pengembangan Hipotesis}

Kepemimpinan merupakan proses penggunaan pengaruh tanpa paksaan untuk membentuk tujuan-tujuan kelompok atau organisasi. Kepemimpinan merupakan hubungan dinamis yang didasarkan pada pengaruh timbal balik antara pemimpin dan pengikut yang menghasilkan tingkat motivasi yang lebih tinggi (Mc Laurin \& Al Amri, 2008). Pemimpin yang mampu mengembangkan pola kepemimpinan sesuai dengan keinginan dan tuntutan anggota organisasi akan mampu meningkatkan kinerja individu dan organisasi.

Penelitian Yulk dan Mashud (2011), mendefinisikan pemimpin adaptif sebagai pemimpin yang bekerja lebih efektif dalam lingkungan yang berubah dengan cepat dengan membantu karyawan untuk memahami tantangan yang dihadapi oleh pemimpin dan pengikut sehingga tepat menanggapi tantangan-tantangan. Pendapat ini didasarkan pada gagasan Yukl dan Mahsud (2010), bahwa para pemimpin adaptif bekerja dengan pengikut mereka untuk menghasilkan solusi kreatif pada masalah-masalah yang kompleks, sehingga bisa mengembangkan pemimpin untuk mampu menangani masalah yang lebih luas yang tanggung jawab kepemimpinan. Penelitian Prewitt et al. (2011) mengidentifikasi kepemimpinan adaptif sebagai pemimpin yang menggunakan beberapa sumber daya untuk memobilisasi pekerjaan, termasuk mengarahkan perhatian, dan menciptakan lingkungan yang mendukung kinerja.

Cameron (1978) mengembangkan model penilaian efektivitas organisasi untuk institusi pendidikan tinggi di Amerika Serikat. Model ini memperkenalkan sembilan dimensi efektivitas organisasi, yaitu: (a) Kepuasan pendidikan mahasiswa; (b) Pengembangan akademik mahasiswa; (c) Pengembangan karier mahasiswa; (d) Pengembangan personal mahasiswa; (e) Kepuasan karyawan administrasi fakultas; (f) Kualitas dan pengembangan profesional fakultas, (g) Keterbukaan sistem dan interaksi komunitas; (h) Kemampuan untuk memperoleh sumber daya dan (i) Kesehatan organisasi. Implementasi dari dimensi tersebut sangat bervariasi sesuai dengan karakteristik penelitian.

Instrumen Cameron tersebut kemudian diadopsi oleh Kwa dan Walker (2004) untuk meneliti institusi pendidikan di Hongkong, dengan beberapa modifikasi. Berikut ini dimensi dan indikator efektivitas organisasi dari 
Cameron yang telah dimodifikasi oleh Kwan \& Wakler (2004).Pendapat tersebut sejalan dengan rambu-rambu yang digunakana untuk menilai program studi oleh Badan Akreditasi Nasional Perguruan Tinggi (BAN-PT).

Kwan dan Walker (2004) mengembangkan model penilaian efektivitas organisasi untuk institusi pendidikan tinggi di Amerika Serikat. Model ini memperkenalkan sembilan dimensi efektivitas organisasi, yaitu: (a) Kepuasan pendidikan mahasiswa; (b) Pengembangan akademik mahasiswa; (c) Pengembangan karier mahasiswa; (d) pengembangan personal mahasiswa; (e) Kepuasan karyawan administrasi fakultas; (f) Kualitas dan pengembangan profesional fakultas, (g) Keterbukaan sistem dan interaksi komunitas; (h) Kemampuan untuk memperoleh sumber daya dan (i) Kesehatan organisasi. Implementasi dari dimensi tersebut sangat bervariasi sesuai dengan karakteristik penelitian.

Penelitian Kouzes dan Posner (2002) mendukung gagasan tentang kepemimpinan adaptif, bahwa dalam lingkungan yang dinamis dewasa ini, hanya individu dan organisasi yang adaptif yang akan berkembang. PenelitianYukl (2002) menjelaskan, bahwa kepemimpinan yang fleksibel dan adaptif adalah penting untuk efektivitas organisasi dan memberikan bimbingan untuk manajer dalam organisasi yang dinamis dan kompetitif saat ini.

Penelitian Glover et al. (2002) menyampaikan empat pilar utama untuk meningkatkan potensi adaptif yaitu: kompetensi budaya, manajemen pengetahuan, menciptakan sinergi dari keanekaragaman, dan visi holistik. Adanya kepemimpinan yang adaptif diharapkan dapat mengurangi konflik, serta meningkatkan kepuasan kerja karyawan dan komitmen organisasi.

Beberapa hasil penelitian menjelaskan hubungan yang signifikan antara konflik dan komitmen organisasi (Chang, 2008). Penelitian-penelitian tersebut menganalisis hubungan konflik secara umum dengan komitmen organisasi. Dalam penelitian ini dipilih variabel resolusi konflik dengan derivasi pada resolusi kolaboratif. Konflik substantif muncul pada saat seseorang melaksanakan tugas yang kurang sesuai dengan latar belakang dan tujuan pribadi. Konflik substantif berkaitan dengan tugas yang dilaksanakan seseorang dalam organisasi. Dalam tataran konflik substantif yang relatif dapat dikendalikan akan meningkatkan komitmen organisasi (Gelfand et al. 2013).

Secara spesifik, penelitian ini menguji variabel resolusi kolaboratif, merujuk hasil penelitian Desivilya dan Yagil (2005), bahwa dari model resolusi yang mempunyai hubungan positif dengan konflik tugas (substantif) adalah pendekatan integratif (kolaboratif/kognitif), dengan munculnya konflik substantif terhadap komitmen organisasi. Pendekatan kolaboratif menurut menurut Kilmann dan Thomas (1977) mengembangkan dua dimensi yaitu kerjasama dan keasertifan secara optimal. Kerjasama merupakan usaha untuk memuaskan orang lain jika menghadapi konflik, sedangkan keasertifan merupakan usaha untuk memuaskan diri sendiri.

H1: Tingkat resolusi kolaboratif yang tinggi akan meningkatkan komitmen afektif.

Pendekatan resolusi kolaboratif dimana konflik dapat diselesaikan dengan cara yang memungkinkan untuk win-win solution merupakan salah satu rujukan bagi pihak-pihak yang terlibat konfik. Jika pendekatan resolusi kolaboratif menjadi pilihan dalam penanganan konflik, maka gaya kepemimpinan yang diterapkan lebih dominan pada gaya adaptif. Penelitian Yulk dan Mashud (2011), menjelaskan, bahwa pemimpin yang adaptif selalu mengoptimalkan dimensi asimilasi dan akomodasi. Gaya kepemimpinan adaptif lebih berorientasi pada keinginan karyawan sesuai dengan kondisi lingkungannya. $\mathrm{H} 2$ : Tingkat resolusi kolaboratif yang tinggi akan meningkatkan gaya kepempinan adaptif integratif.

Proses penanganan konflik substantif dengan pendekatan kolaboratif secara optimal akan menjadikan karyawan merasa dibutuhkan dan tetap berkeinginan untuk tinggal di dalam organisasi jika para pemimpinan mampu mengimplementasikan gaya kepemimpinan yang 
S. Martono \& Andhi Wijayanto / Peningkatan Efektivitas Program Studi di Perguruan Tinggi Swasta ...

Tabel 2. Dimensi Efektivitas Organisasi Institusi Pendidikan

\begin{tabular}{|c|c|c|}
\hline No & Dimensi & Indikator/Item \\
\hline 1. & $\begin{array}{l}\text { Kepuasan pendidikan } \\
\text { mahasiswa }\end{array}$ & $\begin{array}{l}\text { 1. Mahasiswa menikmati kehidupan di kampus } \\
\text { 2. Mahasiswa memelihara hubungan baik dengan fakultas } \\
\text { 3. Mahasiswa memiliki kepuasan yang tinggi dengan program studi } \\
\text { 4. Rata-rata mahasiswa drop out tinggi }\end{array}$ \\
\hline 2. & $\begin{array}{l}\text { Pengembangan } \\
\text { akademik mahasiswa }\end{array}$ & $\begin{array}{l}\text { 1. Mahasiswa mencapai prestasi akademik yang tinggi } \\
\text { 2. Mahasiswa hanya ingin mencapai kualifikasi akademik, } \\
\text { bukan untuk memperoleh pengetahuan }\end{array}$ \\
\hline 3. & $\begin{array}{l}\text { Pengembangan karier } \\
\text { mahasiswa }\end{array}$ & $\begin{array}{l}\text { 3. Mahasiswa sebagai pelajar mandiri } \\
\text { 1. Lulusan dengan mudah mendapatkan pekerjaan setelah mereka lulus } \\
\text { 2. Bekerja sesuai dengan bidang yang mereka pelajari } \\
\text { 3. Sangat direkomendasikan oleh pemberi kerja } \\
\text { 4. Mempunyai gaji yang memadai dibandingkan sesama lulusan dengan jurusan } \\
\text { yang sama di universitas lain }\end{array}$ \\
\hline 4. & $\begin{array}{l}\text { Pengembangan personal } \\
\text { mahasiswa }\end{array}$ & $\begin{array}{l}\text { 1. Mahasiswa sangat memperhatikan kepentingan umum } \\
\text { 2. Aktif dalam kegiatan ekstrakurikuler } \\
\text { 3. Menghormati dosen }\end{array}$ \\
\hline 5. & Kepuasan dosen & $\begin{array}{l}\text { 1. Dosen merasa senang dalam mengajar } \\
\text { 2. Dosen senang melakukan penelitian } \\
\text { 3. Puas dengan lingkungan kerja } \\
\text { 4. Universitas saya merupakan pemberi kerja yang baik } \\
\text { 5. Universitas saya berada dalam rangking tertinggi dalam penelitian dan } \\
\text { publikasi dibandingkan dengan universitas lain di wilayah dan bidang yang }\end{array}$ \\
\hline 6. & $\begin{array}{l}\text { Pengembangan } \\
\text { profesional dan kualitas } \\
\text { fakultas }\end{array}$ & $\begin{array}{l}\text { 1. Dosen mempunyai kualifikasi terbaik dibandingkan dengan universitas lain } \\
\text { diwilayah yang sama } \\
\text { 2. Dosen dipacu dengan penghargaan yang tinggi dalam lingkungan akademik } \\
\text { 3. Universitas saya mendorong dan mendukung pengembangan dosen }\end{array}$ \\
\hline 7. & $\begin{array}{l}\text { Keterbukaan sistem dan } \\
\text { interaksi komunitas }\end{array}$ & $\begin{array}{l}\text { 1. Dosen aktif dalam berbagai pengabdian pada masyarakat } \\
\text { 2. Menekankan pada kebutuhan pemberi kerja } \\
\text { 3. Dosen menikmati reputasi yang bagus dari masyarakat } \\
\text { 4. Menjaga hubungan baik dengan industri atau institusi pendidikan tinggi yang } \\
\text { lain }\end{array}$ \\
\hline 8. & $\begin{array}{l}\text { Kemampuan untuk } \\
\text { memperoleh sumber } \\
\text { daya }\end{array}$ & $\begin{array}{l}\text { 1. Dapat menarik mahasiswa terbaik untuk mendaftar } \\
\text { 2. Dapat menarik dan mempertahankan staff yang mempunyai kualitas bagus } \\
\text { 3. Mampu bekerjasama dengan universitas yang lain dalam memperoleh dana } \\
\text { penelitian } \\
\text { 4. Mampu bekerjasama dengan universitas lain untuk memperoleh sponsor dari } \\
\text { Industri }\end{array}$ \\
\hline
\end{tabular}

mengadopsi kebutuhan dan keinginan para karyawan tersebut. Beberapa hasil penelitian menunjukkan peran pemimpin dalam kaitannya dengan komitmen menunjukkan hasil signifikan seperti Chih dan Lin (2009).

H3: Tingkat gaya kepemimpinan adaptif integratif yang tinggi akan meningkatkan komitmen afektif.

Pengendalian konflik substantif dalam organisasi oleh pimpinan diharapkan mampu meningkatkan kepuasan kerja karyawan. Kepuasan kerja adalah perasaan senang dan positif dari seorang karyawan terhadap proses dan kualitas kerjanya. Kepuasan seseorang dalam bekerja tidak selalu diukur dengan finansial. Persaingan dalam melaksanakan tugas secara positif dapat menciptakan kepuasan seseorang. Pekerjaan kreatif dan inovatif dapat dilakukan apabila didukung peran dan kemampuan pimpinan dalam mengelola organisasi.

H4: Tingkat gaya kepemimpinan adaptif integratif yang tinggi akan meningkatkan kepuasan kerja. 
Berkaitan dengan komitmen dan kepuasan kerja, Karadal et al. (2008) meneliti tentang hubungan komitmen organisasi dan kepuasan kerja di sektor pemerintah dan swasta di Turki. Kepuasan kerja dan komitmen organisasi karyawan merupakan kriteria penting dalam kinerja organisasi. Penelitian Markovits (2007) mengatakan, bahwa komitmen organisasi merupakan variabel yang mempengaruhi kepuasan kerja. Hasil penelitan lain yang menjelaskan bahwa komitmen organisasi berpengaruh positif terhadap kepuasan kerja (Castro, 2008). Kesadaran seseorang untuk tetap loyal pada organisasi dan adanya keinginan untuk selalu terikat dengan organisasi akan membuat seseorang merasa tenang dalam bekerja dan pada akhirnya akan tetap bersemangat dalam menjalankan aktivitasnya.

Pengaruh komitmen organisasi terhadap kepuasan kerja didasarkan pada perilaku dan budaya organisasi yang telah diteliti oleh Meyer et al. (2008) dan Paik et al. (2007). Menurut pandangan teori ini, seseorang yang memiliki komitmen tinggi terhadap organisasi karena memiliki kesamaan dengan nilainilai organisasi yang tercermin dalam budaya organisasi. Keterkaitan terhadap organisasi akan menghasilkan kepuasan kerja. Hubungan ini didasarkan pada alasan, bahwa seseorang dapat mengembangkan komitmen pada saat masuk dan selama mereka berada di dalam organisasi. Argumentasi untuk model ini juga mengadopsi perspektif disonansi kognitif (Huang \& Hsiao, 2007). Setelah seseorang berkomitmen untuk organisasi, mereka akan mengembangkan tingkat kepuasan yang konsisten dengan komitmennya untuk mengurangi disonansi koognitif. H5: Tingkat komitmen afektif yang tinggi akan meningkatkan kepuasan kerja.

Tujuan organisasi akan tercapai jika masing-masing anggota memiliki komitmen untuk tetap bekerja dan berprestasi dalam organisasi tersebut. Hasil penelitian Ussahawanitchakit (2008) menyebutkan, bahwa komitmen organisasi berpengaruh positif dan signifikan terhadap efektivitas organisasi. Hal ini berarti bahwa tingginya komitmen seorang pegawai terhadap organisasi akan meningkatkan efektivitas organisasi. Berdasarkan telaah pustaka dan beberapa hasil penelitian tersebut, hipotesis yang diajukan adalah:

H6: Tingkat komitmen afektif yang tinggi akan meningkatkan efektivitas organisasi.

\section{Kepuasan Kerja dan Efektivitas Organisai}

Efektivitas organisasi dapat terealisasi jika anggota organisasi merasa terpenuhi kebutuhannya, apa yang diperoleh sesuai dengan harapan dan diperlakukan adil dalam organisasi. Penelitian Gelfand et al. (2013) menjelaskan, bahwa ambiguitas peran berpengaruh negatif terhadap kepuasan dan efektivitas organisasi, tetapi kepuasan kerja berpengaruh positif terhadap efektivitas organisasi. Kepuasan yang dirasakan karyawan dalam bekerja membuat komunikasi menjadi lancar, semangat kerja meningkat, perasaan memiliki organisasi menjadi semakin kuat.

H7: Tingkat kepuasan kerja yang tinggi akan meningkatkan efektivitas organisasi.

Berdasarkan eksplorasi model teori yang dikembangkan di atas serta telaah pustaka yang dilakukan, sebuah model penelitian empirik disajikan dalam Gambar 2.

Dari Gambar 2 menunjukkan bahwa, gaya kepemimpinan adaptif integratif bersumber dari resolusi konflik. Konsep yang dibangun dalam penelitian ini adalah variabel gaya kepemimpinan adaptif dan serta dampaknya terhadap komitmen afektif dan kepuasan kerja yang berimplikasi pada efektivitas organisasi.

\section{METODE}

Menurut data di Kopertis 6 terdapat 310 program studi $S 1$ di perguruan tinggi swastadi Kota Semarang yang termasuk dalam kelompok universitas, dan Institut yang berada di bawah Kopertis 6 Jawa Tengah. Dari jumlah tersebut yang terakreditasi "A" dan "B" mencapai 155 program studi. 
S. Martono \& Andhi Wijayanto / Peningkatan Efektivitas Program Studi di Perguruan Tinggi Swasta ...

Model regresi linear berganda dalam penelitian ditunjukkan oleh persamaan berikut:

$$
\mathrm{INST}=\alpha+\beta_{1} \mathrm{LINK}+\beta_{2} \mathrm{KARY}+\beta_{3} \mathrm{PROD}+\varepsilon
$$

Keterangan :

a : konstanta

LINK : Faktor Lingkungan

KARY : Faktor Karyawan

PROD : Faktor Produk

$\varepsilon \quad:$ error

\section{HASIL DAN PEMBAHASAN}

Berikut adalah hasil pengolahan data menggunakan path analisis SEM di sajikan dalam Gambar 3. Dari hasil pengujian seperti pada Gambar 3 di atas menunjukkan, bahwa model dalam penelitian ini sesuai dengan data atau fit terhadap data yang digunakan. Hal ini ditunjukkan dengan nilai Chi-square, probality, CMIN/ DF, GFI, AGFI, TLI dan RMSEA berada pada rentang nilai yang diharapkan.

Data Tabel 4 dipergunakan sebagai dasar perhitungan SEM, tampak bahwa model dapat diterima. Selanjutnya, berdasarkan model fit ini dilakukan pengujian hipotesis yang diajukan dalam penelitian ini melalui analisis regression weights seperti pada Tabel 5. Dari Tabel 5 dapat dikatakan, bahwa setiap variabel memiliki nilai loading factor (koefisien) standardized estimate yang signifikan dengan nilai Critical Ratio.

Berdasarkan model empiris, Hipotesis 1 (H1) yang diajukan dalam penelitian ini, yaitu tingkat resolusi kolaboratif yang tinggi akan meningkatkan komitmen afektif. Hasil perhitungan parameter estimasi antara resolusi kolaboratif dan komitmen afektif menunjukkan nilai parameter beta $(\beta)$ sebesar $=0,875$, standard error estimate parameter $\mathrm{SE}(\beta)=0,094$, nilai $\mathrm{CR}=9,289$, nilai probabilitas tingkat kesalahan $\mathrm{p}=0,000$ dengan taraf signifikansi sebesar $5 \%$. Dengan demikian, Hipotesis 1 didukung. Hasil tersebut menunjukkan bahwa komitmen afektif dipengaruhi variabel resolusi kolaboratif.

Hasil analisis ini mendukung penelitian sebelumnya (Lambert et al., 2006; Karadal et al., 2008), bahwa konflik tugas berpengaruh positif terhadap komitmen organisasi. Secara spesifik dapat dijelaskan, bahwa resolusi kolaboratif yang lebih menekankan pada pentingnya kerjasama dan upaya menciptakan keterbukaan akan mampu membuat seseorang tetap loyal dan selalu berusaha memiliki keterikatan dengan jurusan atau prodi. Dasar pemahaman tentang pentingnya kerjasama menjadi alasan kuat bagi seseorang untuk bekerja sebaik-baiknya.

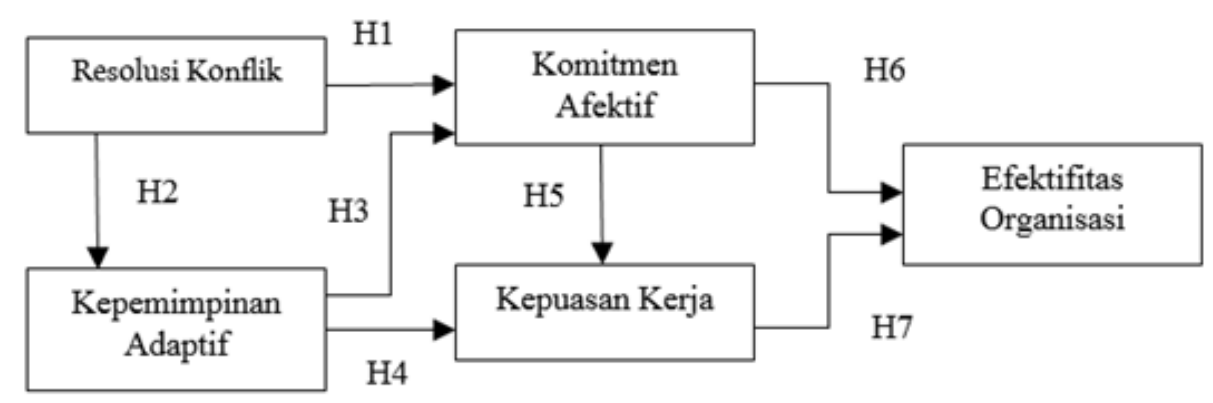

Gambar 2. Model Penelitian Empirik

Tabel 3. Prosedur Pemilihan Sampel

\begin{tabular}{lc}
\hline \multicolumn{1}{c}{ Keterangan } & Jumlah \\
\hline Jumlah Prodi S1 terakreditasi di Kota Semarang & 310 \\
Jumlah Prodi S1 yang masih terakreditasi C & 155 \\
\hline Total sampel yang dipakai tahun 2014 & $\mathbf{1 5 5}$ \\
\hline
\end{tabular}




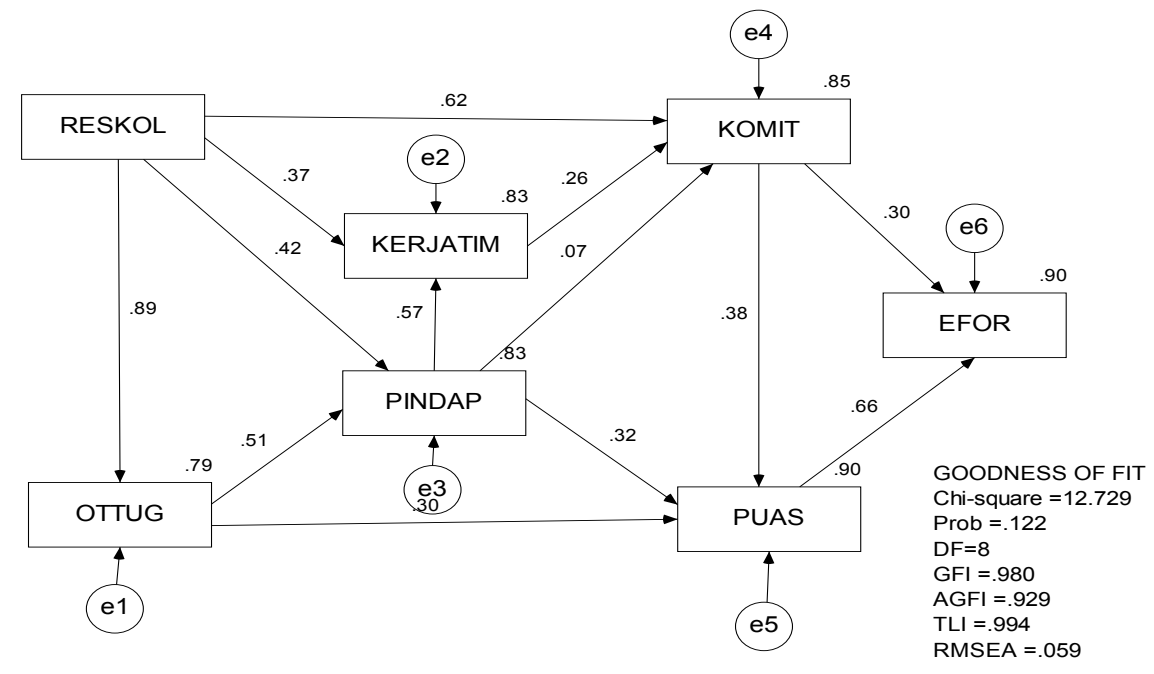

Gambar 3. Hasil Path Analisis SEM

Tabel 4. Indeks Pengujian Kelayakan SEM

\begin{tabular}{lccc}
\hline Goodness-of-fit index & Cut off-value & Hasil & Keterangan \\
\hline Chi-square & 18,307 & 12,729 & Baik \\
Probability & $\geq 0,05$ & 0,122 & Baik \\
RMSEA & $\leq 0,08$ & 0,059 & Baik \\
GFI & $\geq 0,90$ dan mendekati 1 & 0,980 & Baik \\
AGFI & $\geq 0,90$ dan mendekati 1 & 0,929 & Baik \\
CMIN/DF & $\leq 2,00$ & 1,371 & Baik \\
TLI & $\geq 0,90$ dan mendekati 1 & 0,994 & Baik \\
CFI & $\geq 0,90$ dan mendekati 1 & 0,998 & Baik \\
\hline
\end{tabular}

Berdasarkan deskripsi jawaban responden tentang resolusi kolaboratif yang mencakup lima aspek termasuk dalam kriteria sedang dan konsisten dengan jawaban terbuka, bahwa setiap anggota prodi atau jurusan memiliki kewajiban dalam memecahkan masalah, dan harus meluangkan waktu untuk kegiatan prodi atau jurusan, namun kadang-kadang dalam menyikapi kegiatan prodi atau Jurusan tidak kompak karena tanpa musyawarah.

Berdasarkan model empiris, Hipotesis 2 (H2) yaitu tingkat resolusi kolaboratif yang tinggi akan meningkatkan kerjasama tim. Para- meter estimasi antara resolusi kolaboratif dan kerjasama tim menunjukkan nilai parameter beta $(\beta)$ sebesar $=0,452$ standard error estimate parameter $\mathrm{SE}(\beta)=0,081$, nilai $\mathrm{CR}=5,558$, nilai probabilitas tingkat kesalahan $p=0,000$ dengan taraf signifikansi sebesar 5\%, maka Hipotesis 2 didukung. Hasil tersebut mengindikasikan, bahwa kerjasama tim dipengaruhi oleh resolusi kolaboratif. Dapat dikatakan bahwa untuk meningkatkan kerjasama tim harus didukung model resolusi kolaboratif dalam menyelesaikan konflik yang terjadi di tingkat prodi atau jurusan. 
Tabel 7. Regression Weights

\begin{tabular}{lllrrrr}
\hline & & & Estimate & \multicolumn{1}{c}{ S.E. } & \multicolumn{1}{c}{ C.R. } & P \\
\hline OTTUG & $<---$ & RESKOL & .887 & .035 & 25.253 & $* * *$ \\
PINDAP & $<---$ & RESKOL & .385 & .062 & 6.233 & $* * *$ \\
PINDAP & $<---$ & OTTUG & .465 & .062 & 7.526 & $* * *$ \\
KERJATIM & $<---$ & RESKOL & .452 & .081 & 5.558 & $* * *$ \\
KERJATIM & $<---$ & PINDAP & .765 & .090 & 8.542 & $* * *$ \\
KOMIT & $<---$ & RESKOL & .875 & .094 & 9.289 & $* * *$ \\
KOMIT & $<---$ & KERJATIM & .295 & .081 & 3.623 & $* * *$ \\
KOMIT & $<---$ & PINDAP & .111 & .114 & .973 & .330 \\
PUAS & $<---$ & OTTUG & .380 & .069 & 5.507 & $* * *$ \\
PUAS & $<---$ & PINDAP & .451 & .080 & 5.616 & $* * *$ \\
PUAS & $<---$ & KOMIT & .344 & .043 & 8.040 & $* * *$ \\
EFOR & $<---$ & KOMIT & .284 & .052 & 5.425 & $* * *$ \\
EFOR & $<---$ & PUAS & .681 & .058 & 11.813 & $* * *$ \\
\hline
\end{tabular}

Pemahaman tentang pentingnya kerjasama sebagai salah satu indikator kuat dalam resolusi kolaboratif secara empiris akan menentukan seberapa efektif komunikasi yang dapat dibangun untuk mendapatkan dukungan dari masing-masing anggota. Lebih lanjut Slimani et al. (2006) menjelaskan, bahwa upaya penyelesaian masalah yang baik membutuhkan kesediaan kedua kelompok untuk bekerjasama mencari penyelesaian terpadu yang dapat memuaskan kedua kelompok. Hal ini berarti bahwa setiap anggota organisasi harus memahami betapa pentingnya kerjasama dalam suatu organisasi.

Berdasarkan model empiris, Hipotesis 3 (H3) yang diajukan dalam penelitian ini yaitu tingkat kerjasama tim yang tinggi akan meningkatkan komitmen afektif. Parameter estimasi antara kerjasama tim dan komitmen afektif menunjukkan nilai parameter beta $(\beta)$ sebesar $=0,295$ standard error estimate parameter SE $(\beta)=0,081$, nilai $C R=3,623$, nilai probabilitas tingkat kesalahan $\mathrm{p}=0,000$ dengan taraf signifikansi sebesar 5\%. Dengan demikian, hipotesis 3 didukung. Dengan hasil ini dapat dikatakan, bahwa komitmen afektif dipengaruhi oleh kerjasama tim. Hasil tersebut mengindikasikan bahwa untuk meningkatkan komitmen afektif harus didukung kerjasama tim di tingkat prodi atau jurusan.
Sebagai kualitas hubungan sosial, kerjasama tim memberikan kontribusi terhadap keinginan seseorang untuk tetap loyal pada organisasi dalam bentuk keterikatan terutama didasarkan pada ikatan emosional pada organisasi (Meyer et al., 2008). Hasil analisis ini mendukung penelitian Al-Rawi (2008) dan Zientara dan Kuczyński (2009) yang menyatakan bahwa kerjasama tim berpengaruh terhadap komitmen afektif. Secara empiris hasil penelitian ini dapat dijelaskan bahwa kerjasama tim yang didukung komunikasi dinamis dalam kelompok akan membuat seseorang merasa dibutuhkan dan akan berusaha untuk tidak meninggalkan organisasi tersebut.

Berdasarkan model empiris, hipotesis 4 (H4) yang diajukan dalam penelitian ini yaitu tingkat resolusi kolaboratif yang tinggi akan meningkatkan gaya kepempinan adaptif integratif. Hasil perhitungan parameter estimasi antara resolusi kolaboratif dan kepemimpinan adaptif integratif menunjukkan nilai parameter beta $(\beta)$ sebesar $=0,385$ standard error estimate parameter $\mathrm{SE}(\beta)=0,062$, nilai $\mathrm{CR}=6,233$, nilai probabilitas tingkat kesalahan $\mathrm{p}=0,000$ dengan taraf signifikansi sebesar 5\%. Dengan demikian, Hipotesis 4 didukung. Hasil tersebut mengindikasikan, bahwa kepemimpinan adaptif integratif dipengaruhi oleh variabel resolusi kolaboratif. 
Hasil analisis ini didukung fakta, bahwa pemahaman tentang pentingnya kerjasama dan selalu berupaya menciptakan keterbukaan yang didasari adanya perbedaan tercermin dari adanya dukungan kerjasama dari staf administrasi, serta pelaksanaan kegiatan yang telah dilakukan secara transparan dan akuntabel. Kesadaran pentingnya kerjasama menuntut pimpinan untuk dapat memahami karakteristik anggotanya.

Berdasarkan model empiris, Hipotesis 5 (H5) yang diajukan dalam penelitian ini yaitu tingkat gaya kepemimpinan adaptif integratif yang tinggi akan meningkatkan kerjasama tim. Parameter estimasi antara kepemimpinan adaptif integratif dan kerjasama tim menunjukkan nilai parameter beta $(\beta)$ sebesar $=0,765$ standard error estimate parameter $\mathrm{SE}(\beta)=0,090$, nilai $\mathrm{CR}=8,542$, nilai probabilitas tingkat kesalahan $\mathrm{p}=0,000$ dengan taraf signifikansi sebesar 5\%. Dengan demikian, Hipotesis 5 diterima. Hasil tersebut menunjukkan bahwa kerjasama tim dipengaruhi oleh kepemimpinan adaptif integratif. Berdasarkan hasil penelitian mengindikasikan, bahwa untuk meningkatkan kerjasama tim harus didukung gaya kepemimpinan adaptif integratif di tingkat prodi atau jurusan.

Dukungan terhadap diterimanya hipotesis secara empiris dapat dicermati dari jawaban terbuka responden bahwa persepsi pemimpin dalam memahami karakteristik anggota pada aspek perilaku individu dan kelompok, serta kebiasaannya yang didukung oleh semangat kebersamaan dapat membentuk komunikasi dinamis berupa komunikasi lisan dan verbal, secara formal dan informal, serta adanya dukungan bersama berupa ide, gagasan dan totalitas pengabdian dalam bentuk kerjasama yang bertanggungjawab.

Berdasarkan model empiris, Hipotesis 6 (H6) yang diajukan dalam penelitian ini, yaitu tingkat gaya kepemimpinan adaptif integratif yang tinggi akan meningkatkan komitmen afektif. Hasil perhitungan parameter estimasi antara kepemimpinan adaptif integratif dan komitmen afektif menunjukkan nilai para- meter beta $(\beta)$ sebesar $=0,111$ standard error estimate parameter $\mathrm{SE}(\beta)=0,114$, nilai $\mathrm{CR}=$ 0,973 , nilai probabilitas tingkat kesalahan $p$ $=0,330$ dengan taraf signifikansi sebesar 5\%. Dengan demikian, Hipotesis 6 tidak didukung. Hasil tersebut mengindikasikan bahwa komitmen afektif tidak dipengaruhi oleh kepemimpinan adaptif integratif. Berdasarkan hasil tersebut, dapat dikatakan bahwa untuk meningkatkan komitmen afektif tidak didukung gaya kepemimpinan adaptif integratif di tingkat program studi/jurusan.

Hasil penelitian ini secara empiris dapat dijelaskan, bahwa usaha pimpinan untuk memahami karakteristik anggota belum mampu memantapkan seseorang untuk tetap loyal pada jurusan/ prodi. Pemahaman terhadap anggota yang hanya ditekankan sebagai upaya menghormati pendapat orang lain karena faktor usia atau pengalaman, belum sebagai cerminan dapat memahami karakteristik seseorang. Demikian juga halnya dengan upaya menciptakan sinergi, tampak sekali adanya ketidakmerataan dalam distribusi tugas dan akibatnya seseorang belum merasa menjadi bagian dari jurusan/ prodi secara utuh.

Berdasarkan model empiris, Hipotesis 7 (H7) yang diajukan dalam penelitian ini yaitu tingkat resolusi kolaboratif yang tinggi akan meningkatkan otonomi tugas. Parameter estimasi antara resolusi kolaboratif dan otonomi tugas menunjukkan nilai parameter beta $(\beta)$ sebesar $=0,887$ standard error estimate parameter $\mathrm{SE}$ $(\beta)=0,035$, nilai $\mathrm{CR}=25,253$, nilai probabilitas tingkat kesalahan $p=0,000$ dengan taraf signifikansi sebesar 5\%. Dengan demikian, Hipotesis 7 didukung. Berdasarkan hasil tersebut dapat dikatakan bahwa otonomi tugas dipengaruhi oleh resolusi kolaboratif. Hasil tersebut mengindikasikan bahwa untuk mengoptimalkan otonomi tugas harus didukung gaya resolisi kolaboratif dalam menyelesaikan konflik di tingkat program studi atau jurusan.

Hasil perhitungan tersebut secara empiris dapat dijelaskan, bahwa upaya memahami pentingnya kerjasama sebagai indikator resolusi kolaboratif dalam bentuk koordinasi 
dengan semua unsur pimpinan (dekanat, jurusan dan Prodi) dalam memanfaatkan sumber daya yang ada dan selalu menyusun perencanaan, pelaksanaan dan evaluasi program kegiatan secara bersama-sama akan memberikan kesadaran kepada anggota untuk lebih bertanggung jawab dalam mengendalikan pekerjaan. Bentuk pengendalian seperti melakukan monitoring kegiatan secara online, dan menyusun materi pelaporan secara periodik.

Berdasarkan model empiris, Hipotesis 8 (H8) yang diajukan dalam penelitian ini yaitu tingkat otonomi tugas yang tinggi akan meningkatkan gaya kepempimpinan adaptif integratif. Hasil perhitungan parameter estimasi antara otonomi tugas dan kepemimpinan adaptif integratif menunjukkan nilai parameter beta $(\beta)$ sebesar $=0,465$ standard error estimate parameter $\operatorname{SE}(\beta)=0,062$, nilai $C R=7,526$, nilai probabilitas tingkat kesalahan $\mathrm{p}=0,000$ dengan taraf signifikansi sebesar $5 \%$. Dengan demikian, Hipotesis 8 didukung. Hasil tersebut mengindikasikan bahwa kepemimpinan adaptif integratif dipengaruhi oleh otonomi tugas.

Kemampuan mengendalikan tugas dan pekerjaan sesuai dengan wewenang dan tanggung jawabnya melalui monitoring dan evaluasi secara periodik, menetapkan standar operasional dan prosedur (SOP), dan mengembangkan satuan tugas atau gugus akan membuat seseorang dapat memahami jurusan/prodi secara utuh. Pembagian tugas sebagai pembimbing skripsi, PKL/akademik, penentuan dosen penguji, penyusunan jadwal dan merubah kurikulum menjadi dasar pentingnya menciptakan sinergi sehingga dalam pelaksanaannya seorang pemimpin harus melibatkan dosen, staf administrasi, tenaga laboran, pustakawan dan unsur pelaksana lainnya.

Berdasarkan model empiris, Hipotesis 9 (H9) yang diajukan dalam penelitian ini yaitu tingkat gaya kepemimpinan adaptif integratif yang tinggi akan meningkatkan kepuasan kerja. Parameter estimasi antara kepemimpinan adaptif integratif dan kepuasan kerja menunjukkan nilai parameter beta $(\beta)$ sebesar $=0,451$ stan- dard error estimate parameter $\operatorname{SE}(\beta)=0,080$, nilai $\mathrm{CR}=5,616$, nilai probabilitas tingkat kesalahan $\mathrm{p}=0,000$ dengan taraf signifikansi sebesar 5\%. Dengan demikian, Hipotesis 9 didukung. Hal ini menunjukkan, bahwa kepuasan kerja dipengaruhi oleh resolusi kolaboratif. Hasil tersebut mengindikasikan bahwa untuk mengoptimalkan kepuasan dalam bekerja harus didukung gaya kepemimpinan adaptif integratif.

Pemimpin yang memahami perilaku dan adat kebiasaan anggota dan selalu melibatkan semua komponen yang ada seperti dosen, staf administrasi, laboran, pustakawan, kelompok bidang keahlian, gugus atau satuan kerja akan membuat seseorang memperoleh ketenangan dan memiliki semangat untuk tetap bekerja. Ketenangan dalam bekerja dapat diperoleh karena kepercayaan yang diberikan kepada seseorang sehinggan ukuran ketenangan tidak selalu identik dengan imbalan finansial.

Berdasarkan model empiris, Hipotesis 10 (H10) yang diajukan dalam penelitian ini, yaitu tingkat otonomi tugas yang tinggi akan meningkatkan kepuasan kerja. Parameter estimasi antara otonomi tugas dan kepuasan kerja menunjukkan nilai parameter beta $(\beta)$ sebesar $=$ 0,380 standard error estimate parameter $\operatorname{SE}(\beta)$ $=0,069$, nilai $\mathrm{CR}=5,507$, nilai probabilitas tingkat kesalahan $\mathrm{p}=0,000$ dengan taraf signifikansi sebesar 5\%. Dengan demikian, Hipotesis 10 didukung. Hasil tersebut mengindikasikan bahwa kepuasan kerja dipengaruhi oleh otonomi tugas. Mengacu hasil penelitian dapat dikatakan, bahwa untuk mengoptimalkan kepuasan dalam bekerja harus didukung otonomi dalam melaksanakan tugas.

Berdasarkan hasil analisis secara empiris, bahwa seseorang yang memiliki otonomi dalam mengendalikan isi pekerjaan dan menyusun skedul kerja berarti mendapat kepercayaan dan diakui kompetensinya untuk melaksanakan suatu pekerjaan. Kepercayaan dan pengakuan tersebut akan membuat seseorang lebih bersemangat dan akan tetap bekerja pada jurusan/prodi tersebut. Terkait dengan 
reward, otonomi dalam hal menangani pekerjaan dan menyusun skedul kerja akan mendapat penghargaan sesuai dengan besarnya tanggung jawab yang dilaksanakan.

Berdasarkan model empiris, Hipotesis 11 (H11) yang diajukan dalam penelitian ini yaitu tingkat komitmen afektif yang tinggi akan meningkatkan kepuasan kerja. Parameter estimasi antara komitmen afektif dan kepuasan kerja menunjukkan nilai parameter beta $(\beta)$ sebesar $=0,344$ standard error estimate parameter $\operatorname{SE}(\beta)=0,043$, nilai $\mathrm{CR}=8,040$, nilai probabilitas tingkat kesalahan $p=0,000$ dengan taraf signifikansi sebesar 5\%. Dengan demikian, Hipotesis 11 didukung. Hasil penelitian tersebut menunjukkan, bahwa kepuasan kerja dipengaruhi oleh komitmen afektif. Merujuk hasil tersebut dapat dikatakan, bahwa untuk meningkatkan kepuasan kerja harus didukung komitmen afektif.

Secara empiris berdasarkan data penelitian dapat dijelaskan, bahwa seseorang yang memiliki loyalitas tinggi pada jurusan/prodi dalam bentuk pelaksanaan tugas dengan penuh tanggung jawab, didukung suasana kerja yang nyaman dan adanya peluang untuk berkembang akan membuat seseorang tenang dan selalu bersemangat dalam bekerja. Demikian juga halnya dengan perasaan bangga terhadap jurusan/ prodi karena merasa menjadi bagian di dalamnya akan menyebabkan seseorang bertahan dan selalu berusaha mengembangkan jurusan/prodi.

Berdasarkan model empiris, Hipotesis $12(\mathrm{H} 12)$ yang diajukan dalam penelitian ini yaitu tingkat komitmen afektif yang tinggi akan meningkatkan efektivitas organisasi. Hasil perhitungan parameter estimasi antara komitmen afektif dan efektivitas organisasi menunjukkan nilai parameter beta $(\beta)$ sebesar $=0,284$ standard error estimate parameter $\mathrm{SE}$ $(\beta)=0,052$, nilai $C R=5,425$, nilai probabilitas tingkat kesalahan $\mathrm{p}=0,000$ dengan taraf signifikansi sebesar 5\%. Dengan demikian, Hipotesis 12 didukung. Hasil tersebut mengindikasikan, bahwa efektivitas organisasi dipengaruhi oleh komitmen afektif.
Perasaan bangga menjadi bagian dari jurusan/prodi akan tertanam sikap memiliki, membela dan mempertahankan jurusan/prodi. Hal ini akan berdampak pada meningkatnya kualitas akademik khususnya pada aspek pembelajaran. Keinginan untuk meningkatkan kualitas jurusan/prodi sebagai bentuk komitmen dan loyalitas akan mendorong dosen melakukan tri dharma secara optimal. Peningkatan tri dharma, khususnya bidang penelitian, akan berdampak pada peningkatan publikasi hasil penelitian.

Berdasarkan model empiris, Hipotesis 13 (H13) yang diajukan dalam penelitian ini yaitu tingkat kepuasan kerja yang tinggi akan meningkatkan efektivitas organisasi. Hasil perhitungan parameter estimasi antara kepuasan kerja dan efektivitas organisasi menunjukkan nilai parameter beta $(\beta)$ sebesar $=0,681$ standard error estimate parameter $\mathrm{SE}(\beta)=0,058$, nilai $\mathrm{CR}=11,813$, nilai probabilitas tingkat kesalahan $\mathrm{p}=0,000$ dengan taraf signifikansi sebesar 5\%. Dengan demikian, Hipotesis 13 didukung. Hasil tersebut mengindikasikan bahwa efektivitas organisasi dipengaruhi oleh kepuasan kerja.

Seseorang yang memperoleh ketenangan dalam bekerja karena apa yang diharapkan telah terpenuhi dan berkeinginan untuk tetap bekerja di jurusan/prodi tertentu akan berpeluang untuk lebih aktif, kreatif dan inovatif. Ciri-ciri seseorang yang aktif, kreatif dan inovatif adalah meraka tidak akan pernah merasa cukup dengan prestasi yang diraih saat ini. Perasaan selalu terdorong untuk berbuat yang lebih baik sehingga dapat dikatakan, bahwa hasil akhir dari kegiatan tersebut adalah meningkatkan kualitas jurusan/prodi, khususnya aspek pembelajaran dan penelitian.

Memperhatikan hasil uji hipotesis di atas dapat di ketahui bahwa Hipotesis 7 yaitu "tingkat resolusi kolaboratif yang tinggi akan meningkatkan otonomi tugas" memiliki nilai koefisien yang paling tinggi yaitu sebesar 0,885 . Hal ini dapat dijelaskan bahwa secara empiris, pendekatan kolaborasi paling sering digunakan untuk menyelesaikan konflik (Slimani, 2006) 
dengan alasan mampu mendorong hubungan interpersonal, dan mampu mengembangkan iklim organisasi yang lebih terbuka. Hasil analisis ini konsisten dengan otonomi dalam menjalankan tugas yang menekankan bagaimana mekanime kerja dilakukan. Otonomi dapat dilakukan seseorang dalam melaksanakan tugas jika tidak menghambat pencapaian tujuan dan tidak mengurangi kualitas tugas yang menjadi tanggung jawabnya. Otonomi tugas berarti tingkat kebebasan mengembangkan pola dan strategi dalam menyelesaikan tugas atau pekerjaan (Patillo, 2009). Kebebasan bagi seseorang dalam menyelesaikan pekerjaan harus didukung dengan pengendalian isi pekerjaan, sehingga kebebasan yang dimiliki oleh seseorang tetap terikat pada substansi pekerjaan. Otonomi juga berkaitan dengan kebebasan, dalam menangani pekerjaan, menentukan jadwal penyelesaian, dan kekuasaan dalam memulai pekerjaan.

Pendekatan kolaboratif dipandang relatif ideal dalam penyelesaian konflik meskipun sangat sulit diimplementasikan (Ivancevich, 2009 \& Slimani, 2006). Upaya penyelesaian masalah yang baik membutuhkan kesediaan kedua kelompok untuk bekerjasama mencari penyelesaian terpadu yang dapat memuaskan kedua kelompok. Ketika pihak-pihak yang saling bertentangan benar-benar berkolaborasi, kemungkinan akan mendapatkan pemahaman, pengalaman, dan cara pandang baru yang dapat menciptakan solusi-solusi berkualitas. Kebebasan melakukan inovasi dan kreasi di tempat kerja yang berkaitan dengan tugas dan pekerjaannya harus didukung oleh kesediaan karyawan untuk menerima kritik dan masukan pihak lain, terutama pimpinan, agar tetap dalam batas-batas kewenangannya.

\section{SIMPULAN DAN SARAN}

Penelitian ini dilaksanakan dengan maksud untuk melakukan pengujian terhadap variabel-variabel yang mempengaruhi gaya kepemimpinan adaptif integratif, kerjasama tim, komitmen afektif dan kepuasan kerja serta imp- likasinya terhadap efektivitas organisasi pada program studi/jurusan Perguruan Tinggi Negeri dan Perguruan Tinggi Swasta di Jawa Tengah. Dukungan Hipotesis 1, 2, 3, 4, 5 dan 13 menjawab pertanyaan penelitian pertama bahwa resolusi kolaboratif dapat meningkatkan kerjasama tim, komitmen afektif dan efektivitas organisasi jurusan/prodi. Resolusi kolaboratif dapat meningkatkan komitmen afektif melalui kerjasama tim. Dukungan Hipotesis 4, 7, 8, 9 dan 10, menjawab pertanyaan penelitian kedua, bahwa resolusi kolaboratif dapat meningkatkan kepuasan kerja. Resolusi kolaboratif dapat meningkatkan kepuasan kerja melalui otonomi tugas dan kepemimpinan adaptif integratif.

Dukungan Hipotesis 3, 5, 9, 11, 12 dan 13 menjawab pertanyaan penelitian ketiga, bahwa gaya kepemimpinan adaptif integratif dapat meningkatkan kepuasan kerja dan efektivitas organisasi jurusan/prodi. Gaya kepemimpinan adaptif intergratif dapat meningkatkan efektivitas organisasi jurusan/ prodi melalui kepuasan kerja, kerjasama tim, dan komitmen afektif. Dukungan Hipotesis 8, 9, 10 dan 12 menjawab pertanyaan penelitian keempat, bahwa otonomi tugas dapat meningkatkan efektivitas organisasi jurusan/ prodi yaitu melalui kepemimpinan adaptif, dan kepuasan kerja. Otonomi tugas dapat meningkatkan kepuasan kerja secara langsung atau melalui kepemimpinan adaptif integratif. Otonomi tugas dapat meningkatkan efektivitas organisasi jurusan/prodi melalui kepempinan adaptif integratif dan kepuasan kerja.

Berdasarkan hipotesis-hipotesis yang telah dikembangkan dalam penelitian ini, maka masalah penelitian yang telah diajukan dapat dijustifikasi melalui Structural Equation Modeling, dapat ditentukan, bahwa hubungan antara variabel-variabel yang mempengaruhi dan dipengaruhi dan pada akhirnya sampai pada variabel efektivitas organisasi dari enam konstruk yang diajukan dan didukung secara empirik adalah (1) Resolusi Kolaboratif, (2) Kerjasama Tim, (3) Kepemimpinan Adaptif Integratif, (4) Otonomi Tugas, (5) Komitmen Afektif dan (6) Kepuasan Kerja. 
Berdasarkan hasil pengembangan model teoritis seperti yang disajikan dalam model konseptual implementasi gaya kepemimpinan dalam upaya peningkatan komitmen, kepuasan kerja dan efektivitas organisasi maupun pengembangan dan pengujian model empiris yang dilakukan meninggalkan bebarapa agenda penelitian lanjutan. Pertama, penelitian empiris ini belum mampu memberikan jawaban peran kepemimpinan adaptif integratif dalam hubungannya dengan resolusi kolaboratif dalam menyelesaikan konflik dan komitmen afektif. Hal ini didasarkan atas hasil analisis pengaruh yang tidak signifikan kepemimpinan adaptif integratif terhadap komitmen afektif. Untuk itu, sebuah penelitian lanjutan dapat dilakukan dengan mengembangkan konstruk komitmen organisasi yang mencakup afektif, kuntinuan dan normatif. Dengan demikian, diharapkan dapat diketahui peran kepemimpinan adaptif integratif dalam hubungannya dengan resolusi kolaboratif dan komitmen organisasi.

Kedua, penelitian empiris ini belum mampu menjelaskan pengaruh otonomi tugas terhadap komitmen afektif melalui gaya kepemimpinan adaptif integratif. Untuk itu, sebuah penelitian lanjutan dapat dilakukan untuk mengukur peran kepemimpinan adaptif integratif terhadap hubungan antara otonomi tugas dan komitmen afektif. Ketiga, penelitian empirik ini belum mengukur hubungan antara gaya kepemimpinan adaptif integratif dan efektivitas organisasi. Dengan demikian, agenda penelitian lanjutan dapat dilakukan dengan mengukur tingkat pengaruh antara kepemimpinan adaptif integratif terhadap efektivitas organisasi. Hal ini juga dapat digunakan untuk mengetahui pengaruh tidak langsung resolusi kolaboratif dan otonomi tugas terhadap efektivitas organisasi melalui gaya kepemimpinan adaptif integratif. Keempat, penelitian empirik ini belum mengukur hubungan resolusi kolaboratif terhadap efektivitas organisasi melalui kepuasan kerja.

Dengan demikian, penelitian ini belum mengisi celah antara resolusi kolaboratif dan efektivitas organisasi sehingga agenda penelitian lanjutan dapat dilakukan untuk menjawab dan mengisi celah tersebut dengan melalui me- diasi kepuasan kerja. Kelima, penelitian empiris ini belum memasukkan variabel budaya organisasi dalam upaya peningkatan komitmen, kepuasan kerja dan efektivitas organisasi. Untuk itu, agenda penelitian lanjutan dapat dilakukan dengan memasukkan variabel budaya organisasi dan hubungannya dengan gaya kepemimpinan, resolusi konflik, otonomi tugas, dan kerjasama t

\section{DAFTAR PUSTAKA}

Ali, N \& Baloch, Q. B. 2010. Job Satisfaction and Employees Turnover Intention (Case Study of NWFP Pakistan Based Banking Sector). Interdisciplinary Journal of Contemporary Research In Business. 2 (5): 39-63.

Al-Rawi, K. 2008. Cohesiveness Within Teamwork: The Relationship to Performance Effectiveness-Case Study. Education, Business and Society: Contemporary Middle Eastern Issues. 1 (2): 92-106.

Burke, B. F. 2007. Adaptive Leadership As A Facilitator Of Public Engagement On Environmental. Sustainability Issues Administrative Theory \& Praxis. 29 (3): 412-431.

Castro, C. B., Perinan, M. M. P \& Bueno, J. C. C. 2008. Transformational leadership and followers' attitudes: the mediating role of psychological empowerment. The International Journal of Human Resource Management. 19 (10): 1842-1863.

Caykoylu, S., Egri, C. P \& Havlovic, S. 2007. Organizational Commitment Across Different Employee Groups. The Business Review. 8 (1): 191-197.

Chan, J. M., Pan, Z \& Lee, F. L. F. 2004. Professional Aspirations and Job Satisfaction: Chinese Journalists at A Time of Change in The Media. Journalism and Mass Communication Quarterly. 81 (2): 254-273.

Chang, S. 2008. Work Role Stressors and Turnover Intentions: A Study of IT Personnel in South Korea. Zeitschrift für Personal forschung. 22 (3): 272-290.

Chih, W \& Lin, Y. 2009. The Study of The Antecedent Factors of Organisational Commitment for High-Tech Industries in Taiwan. Total Quality Managemen. 20 (8): 799-815.

Derue, D. S., Nahrgang, J. D., Wellman, N \& Humphrey, S. E. 2011. Trait and Behavioral Theories of Leadership: An Integration and Meta-Analytic Test of Their Relative Validity. 
Personnel Psychology. 64 (1): 7-52.

Desivilya, H. S \& Yagil, D. 2005. The Role of Emotions In Conflict Management: The Case of Work Teams. The International Journal of Conflict Management. 16 (1): 55-69.

Euwema, M. C., Fliert, D. E. V \& Baker, A. B. 2003. Subtantive and Relational Effectiveness of Organizatinal Conflict Behavior. The International Journal Of Conflict Management. 14 (2): 119-139.

Fitriastuti, Triana. 2013. Pengaruh Kecerdasan Emosional, Komitmen Organisasional, dan Organizational Citizenship Behavior Terhadap Kinerja Karyawan. Jurnal Dinamika Manajemen. 4 (2): 103-114.

Furumo, K. 2009. The Impact of Conflict and Conflict Management Style on Deadbeats and Deserters In Virtual Teams. Journal Of Computer Information Systems. 49 (4): 66-73.

Galup, S. D., Gary, K \& Jiang, J. J. 2008. The Impacts of Job Characteristics on is Employee Satisfaction: A Comparison Between Permanent And Temporary Employees. Journal of Computer Information Systems. 48 (4): 58-69.

Gelfand, M J. K., Keller \& Leslie, M. 2013. Conflict Culture in Organization: How Leader Shape Conflict Culture and their Organization Level Consequences. Journal of Aplied Psychology. 97 (6): 1131-1147.

Griffin, R. W. 2012. Management, 7th Edition. Boston: Houghton Mifflin Company.

Huang, T \& Hsiao, W. 2007. The Causal Relationship Between Job Satisfaction and Organizational Commitment. Scientific Journal Publishers. 35 (9): 1265-1276.

House, R. J. 1971. A Path Goal Theory of Leader Effectiviness. Administrative Science Quarterly. 16 (3): 321-339.

Jehn, K. A. 1995. A Multimethod Exannination of the Benefits and Detriments of Intragroup Conflict. Administrative Science Quarterly. 40 (2): 256-282.

Karadal, H., Ay, U \& Cuhadar, M. T. 2008. The Effect of Role Conflict and Role Ambiguity on Job Satisfaction and Organizational Commitment: A Study in the Public and Private Sectors. The Journal of American Academy of Business, Cambridge. 13 (2): 176-181.

Kok-Yee, N., Ang, S \& Chan, K. 2008. Personality and Leader Effectiveness: A Moderated Mediation Model of Leadership Self-Efficacy, Job Demands, and Job Autonomy. Jour- nal of Applied Psychology. 93 (4): 733-743.. Kwan, P \& Walker, A. 2004. Validating The Competing Values Model As A Representation Of Organizational Culture Through Inter-Institutional Comparisons. Organizational Analysis. 12 (1): 21-37.

Lambert, E. G., Pasupuleti, S., Cluse-Tolar, T., Jennings, M \& Baker, D. 2006. The Impact of Work-Family Conflict on Social Work and Human Service Worker Job Satisfaction and Organizational Commitment: An Exploratory Study. Administration in Social Work. 30 (3): 55-57.

Leung, M., Chen, D \& Yu, J. 2008. Demystifying Moderate Variables of the Interrelationships among Affective Commitment, Job Performance, and Job Satisfaction of Construction Professionals. Journal of Construction Engineering and Management. 134 (12): 963-971.

Lichtenstein, B. B., Uhl-Bien, M., Marion, R., Seers, A., Orton, J. D \& Schreiber, C. 2006. Complexity leadership theory: An Interactive Perspective On Leading In Complex Adaptive Systems. Emergence: Complexity ఓ Organization. 8 (4): 2-12.

Markovits, J., Davis, A. J \& Dick, R. V. 2007. Organizational Commitment Profiles and Job Satisfaction among Greek Private and Public Sector Employees. International Journal of Cross Cultural Management. 7 (1): 77-99.

McLaurin, J. R \& Al Amri, M. B. 2008. Developing An Understanding of Charismatic and Transformational Leadership. Proceedings of the Academy of Organizational Culture, Communications and Conflict. 13(2): 15-19.

Meyer, J. P., Stanley, D. J., Hersovitch, L \& Topolnytsky, L. 2008. Affective, Continuance, and Normative Commitment to the Organization: A Meta Analysis of Antecedents, Correlates, and Concecuences. Journal of Vocational Behavior. 61: 20-52.

Morris, M. G \& Venkatesh, V.2010. Job Characteristics and Job Satisfaction: Understanding The Role Of Enterprise Resource Planning System Implementation. Mis Quarterly. 34 (1): 143-161.

Moynihan, D. P \& Pandey, S. K. 2007. Finding Workable Levers Over Work Motivation Comparing Job Satisfaction, Job Involvement, and Organizational Commitment. Administration \& Society. 39 (7): 803-832.

Patillo, E. J., Moran, B. B \& Morgan, J. C. 2009. The Job Itself: The Effects of Functional Units 
on Work Autonomy among Public and Academic Librarians. Library Trends. Fall 2009 ("Workforce Issues in LIS." edited by Joanne Gard Marshall, Paul Solomon, and Susan Rathbun-Grubb). 58 (2): 276-290.

Prewitt, J. F., Weil, R \& McClure, A. Q. 2011. Cricis Leadership An Organizationonal Opportunity. Journal Business and Management Research. 1(5): 60-74.

Ranihusna, Desti. 2010. Efek Rantai Motivasi Pada Kinerja Karyawan. Jurnal Dinamika Manajemen. 1 (2): 90-103.

Slimani, K.., Silva, C. F. D., Medini, L \& Ghodous, P. 2006. Conflict mitigation in collaborative design. International Journal of Production Research. 44 (9): 1681-1702.

Kilmann, R. H \& Thomas, K. W. 1977. Developing a Forced-Choice Measure of ConflictHandling Behavior: The MODE Instrument. Educational and Psychological Measurement. 37 (2): 309-325.

Tjosvold, D., Law, K. S \& Sun, H. 2006. Effectiveness of Chinese Teams: The Role of Conflict Types and Conflict Management Approaches. Management and Organization Review. 2 (2): 231-252.
Ussahawanitchakit, P. 2008. Organizational Learning Capability, Organizational Commitment, and Organizational Effectiveness: An Empirical Study Of Thai Accounting Firms. International Journal of Business Strategy. 8 (3): 1-12.

Paik, Y., Parboteeah, K. P \& Shim, W. 2007. The Relationship Between Perceived Compensation, Organizational Commitment and Job Satisfaction: The Case Of Mexican Workers In The Korean Maquiladoras. The International Journal of Human Resource Management. 18 (10): 1768-1781.

Yukl, G \& Mahsud, R. 2010. Why Flexible and Adaptive Leadership is Essential. Consulting Psychology Journal. 62 (2): 81-93.

Zientara, P \& Kuczynski, G. 2009. Human Resources Practices and Work-Related Attitudes in Polish Public Administration. Eastern European Economics. 47 (5): 42-60.

Zakuan, N., Shalini M., Muhamad, Z. M. S., Mohd, S. M. A \& Rozita, A. J. 2012. Critical Succes Factors of Total Quality Management Implementation in Higer Education Institution. International Journal of Academic Research in Business and Social Sceness. 2 (12): 19-32. 